\title{
Bovine Steroid Hormone and SHBG Concentrations Postpartum and during the Oestrous Cycle
}

\author{
By M. Vesanen, V. Isomaa, N. J. Bolton, M. Alanko and R. Vihko \\ Department of Clinical Chemistry, University of Oulu, and \\ Farmos Diagnostica, Oulunsalo, and Department for Obstetrics and Gynaecology, \\ College of Veterinary Medicine, Hautjärvi, Finland.
}

\begin{abstract}
Vesanen M., V. Isomaa, N. J. Bolton, M. Alanko and R. Vihko: Bovine steroid hormone and SHBG.concentrations postpartum and during the oestrous cycle. Acta vet. scand. 1990, 31, 459-469. - Changes in consecutive estimates of milk progesterone concentrations and serum steroid hormone and sex hormone-binding globulin (SHBG) concentrations in the postpartum period were examined in Finnish Ayrshire and Friesian dairy cows which were divided according to feeding into a hay group and a silage group. Milk progesterone concentrations rose above $10 \mathrm{nmol} / \mathrm{l}$, indicating the start of ovarian luteal activity, slightly earlier in the silage group $(28.4 \pm 8.7$ (S.D.) days, $n=19)$ than in the hay group $(33.4 \pm 10.3, n=28)$ after calving. Likewise, the first normal oestrous cycles began slightly earlier in cows fed with silage. On the other hand, no differences in the beginning of ovarian luteal activity were observed between the breeds. Serum oestradiol-17 $\beta$, oestrone, testosterone, $5 \alpha$-dihydrotestosterone $(5 \alpha$-DHT), pregnenolone and progesterone concentrations were fairly unchanged during postpartum anoestrus after uterine involution and before ovarian cyclic activity. After first ovulation, considerable increases in milk and serum progesterone concentrations were observed. The increase was accompanied by elevations in serum pregnenolone and $5 a-\mathrm{DHT}$ concentrations. In the late luteal phase, progesterone, $5 a$-DHT and pregnenolone concentrations rapidly declined, leading to low hormone levels in pro-oestrus. Thereafter, serum pregenolone and $5 \alpha$-DHT concentrations slightly increased during the follicular phase. On the other hand, oestradiol-17 $\beta$ concentrations were elevated in pro-oestrus and decreased after that, being lowest at met-oestrous. Serum testosterone concentrations appeared to be unchanged during postpartum anoestrus and over the oestrous cycle. Serum SHBG concentrations were unchanged during postpartum anoestrus and over the oestrous cycle, as well as in pregnant animals. The serum SHBG concentrations were about double those found in women with normal menstrual cycles, whereas oestradiol concentrations were much lower. At present, it cannot be explained how the biological effects of oestradiol become evident under such conditions.
\end{abstract}

milk progesterone; serum steroids; sex hormone binding globulin.

\section{Introduction}

In cows, milk progesterone concentrations are widely used for pregnancy diagnosis and the detection of oestrus and ovarian cyclic activity (Heap et al. 1976, Hoffman et al. 1976, Shemesh et al. 1978). Analysis of sequential milk samples can be an aid in the diagnosis of fertility problems (Lamming \&
Bulman 1976, Bulman \& Lamming 1978) and in evaluation of drug efficacy in the treatment of such problems (Lamming \& Bulman 1976, Bulman et al. 1978).

Bovine serum progesterone, oestradiol and oestrone concentrations during the oestrous cycle have also been the subject of many studies (Webb et al. 1980, Dobson 1978, Schal- 
lenberger et al. 1985), but serum pregnenolone, testosterone and $5 \alpha$-dihydrotestosterone $(5 \alpha-\mathrm{DHT})$ concentrations are not well established after calving in dairy cows. Bovine sex hormone-binding globulin (SHBG) has been characterized previously (Suzuki et al. 1977, Suzuki \& Sinohara 1984), but variations of SHBG concentrations in physiological conditions have not been reported.

In the present study, consecutive milk progesterone measurements were carried out to evaluate the beginning of ovarian cyclic activity and the variations in progesterone production. These progesterone measurements, combined with repeated clinical examinations, were used to evaluate different stages of the genitals and the oestrous cycle. Simultaneous measurements of serum steroid hormone and SHBG concentrations in these carefully defined periods would be valuable for better understanding the reproductive endocrinology of cows in the postpartum period. They would also complement the information available on regulation of oestrogen and progesterone receptors in bovine endometrium (Vesanen et al. 1988). In addition, we compared 2 breeds, Ayrshire and Friesian, and 2 different feeds based on silage or on hay and urea.

\section{Materials and methods}

\section{Animals and collection of samples}

The animals consisted of Finnish Ayrshire and Friesian cows which were divided into 2 feeding groups. Group 1 was fed dried hay and grain meal containing $2 \%$ urea, while group 2 was fed silage and grain meal. All the cows had calved more than once. Parturition events, for example retained placental membranes and clinical or subclinical (evaluated by histology) pathological conditions of the endometrium after parturition were recorded. Cows having abnormalities postpartum in ovarian function were excluded from this investigation. Examination of the uterus and ovaries by rectal palpation started 10 days postpartum and was performed twice a week until the first signs of approaching oestrus, after which they were performed daily. The degree of uterine involution, as well as follicles and corpora lutea in the ovaries, were recorded. The functional status of the ovaries was evaluated by consecutive rectal palpations and milk progesterone measurements.

The collection of milk specimens for progesterone assay was performed immediately after normal milking. The first milk specimen was taken 10 days postpartum and sampling was continued twice a week until the first artificial insemination, which took place at the earliest 2 months after calving. Milk samples were preserved with sodium azide tablets and stored in a refrigerator before examination. Collection of blood samples from the vena subcutanea abdominalis for serum steroid hormone measurements was performed without anticoagulant. The serum was separated by centrifugation and frozen at $-20^{\circ} \mathrm{C}$. A piece of endometrium was taken by biopsy for histological study to evaluate the status of the uterus. This piece was fixed for 1 day in Bouin's solution and transferred into $70 \%$ ethanol solution. Histological slides were prepared and stained with haematoxylin-eosin. The first serum specimens were taken after parturition (on average $27 \pm 9$ (S.D.) days) when uterine involution had taken place but cyclic function of the ovaries and production of progesterone from the corpus luteum had not begun. This period is named postpartum anoestrus later in this text. Later samples were taken either in the follicular (oestrus) or luteal (dioestrus) phases of normal cycles. The follicular phase specimens were taken during the first or second visible oestrus postpartum and were divided into 3 groups: 
pro-oestrus, oestrus and metoestrus specimens. Pro-oestrus was defined as the state when the milk progesterone concentration had declined (after dioestrus) to below 10 nmol/l, serum progesterone was below 2.7 $\mathrm{nmol} / \mathrm{l}$ and symptoms of approaching oestrus were observed by rectal palpation of the ovaries and uterus. True oestrus was defined as the state where clear symptoms of oestrus were clinically detected and the normal preovulatory follicle could be palpated in the ovary. Metoestrus was defined as the period after ovulation until milk progesterone concentrations had increased to above $10 \mathrm{nmol} / \mathrm{l}$ and those of serum progesterone were above $2.7 \mathrm{nmol} / \mathrm{l}$. Samples taken during dioestrus were also divided into 3 groups according to time: early, i.e. the first third of dioestrus, the middle of dioestrus, and late, i.e. the last third of dioestrus.

\section{Measurement of steroid hormone concen- trations}

Measurement of whole milk progesterone concentrations was performed using radioimmunoassay reagent sets produced by Farmos Diagnostica (Turku, Finland) following the instructions given by the manufacturer. The only modifications were that labelled $\left[{ }^{125} \mathrm{I}\right]$ progesterone was pipetted into all tubes before the antiserum solution and the incubation was thereafter performed at room temperature instead of in a refrigerator. Progesterone measurements of standards and milk samples were carried out in duplicate.

Measurement of serum pregnenolone, progesterone, testosterone and $5 \alpha$-DHT concentrations was performed by individual radioimmunoassays after solvent extraction and chromatographic purification of samples as described previously (Apter et al. 1976, Hammond et al. 1978, Leinonen 1980, Bolton et al. 1985). Briefly, unconjugated steroids were extracted from $2 \mathrm{ml}$ of serum and then fractionated on Lipidex $5000^{\mathrm{TM}}$ microcolumns (Packard - Becker, B.V., Chemical Operations, Netherlands) followed by radioimmunoassay of each steroid from the appropriate fraction using antisera of defined specificity (Jänne et al. 1974, Apter et al. 1976). The chromatographic fractionations of oestrone $\left(E_{1}\right)$ and oestradiol-17 $\beta\left(E_{2}\right)$, extracted from separate serum specimens, were performed as described by Leinonen (1980). The appropriate fractions were analysed for $E_{2}$ using commercial RIA kits (Farmos Diagnostica, Oulunsalo, Finland) according to the instructions given by the manufacturer. Radioimmunoassay of $E_{1}$ after chromatography was performed using highly specific antisera (Inter Sci Diagnostics, California, USA) and [25I]-labelled $E_{1}$ (Farmos Diagnostica, Oulunsalo, Finland).

\section{Assay of serum SHBG concentrations}

The serum concentrations of bovine SHBG were determined in binding assays employing $\left[{ }^{3} \mathrm{H}\right] 5 \alpha$-DHT, as described by Hammond \& Lähteenmäki (1983). In 2 cases, Scatchard-type analysis was carried out using a range $(n=9)$ of concentrations of tracer, and sets of tubes containing 200-fold molar excesses of unlabelled $5 \alpha$-DHT to monitor non-specific binding at each concentration of tracer. In comparison to $5 \alpha$-DHT, the relative binding affinities (RBAs) of testosterone, $E_{2}$ and progesterone were determined. Ranges of concentrations of unlabelled steroids were added to tubes in binding assays, which were otherwise carried out normally. Percentage RBAs were calculated at $50 \%$ displacement of labelled $5 \alpha$-DHT.

\section{Other methods}

Statistical comparisons of the results were performed by one-way analysis of variance 
and t-statistics by the Bonferroni method (Wallenstein et al. 1980). Linear regression analysis was used to evaluate the correlations.

\section{Results \\ Beginning of ovarian cyclic activity after parturition}

Since serum and milk progesterone concentrations correlate well, milk progesterone determinations were used to monitor luteal activity. Progesterone concentrations in milk rose above $10 \mathrm{nmol} / \mathrm{l}$ on average $31.4 \pm 9.9$ (S.D.), $(n=47)$ days postpartum, indicating the start of ovarian luteal activity after calving. Elevated progesterone concentrations in milk were observed slightly earlier in the silage group (28.4 \pm 8.7 (S.D.) days, $n=19)$ than in the hay group $(33.4 \pm 10.3$ days, $n=$ 28) but there was no significant difference between the 2 breeds (Table 1). In $34 \%$ of the animals the first luteal phase and therefore the whole cycle was shorter than normal (milk progesterone $>10 \mathrm{nmol} / \mathrm{l}$, but duration of the whole cycle $<17$ days). These short cycles were followed by normal oestrous cycles. The duration of postpartum anoestrus was variable. However, ovarian luteal activity had begun in $81 \%$ of the animals 40 days after parturition. If ovarian activity had started by 30 days after parturi- tion the conception rate after the first artificial insemination was higher $(71 \%, \mathrm{n}=21)$ than in those cows which started cyclic activity later than 30 days postpartum ( $43 \%$, n =23).

Retained placental membranes and endometritis (evaluated by histology) had no effect on the beginning of ovarian cyclic activity (31.1 \pm 9.0 days, $n=8)$, although the period from parturition to conception (106.9 \pm 47.1 days, $n=7$ ) was prolonged in these animals compared with cows having no endometrial disorders $(84.0 \pm 22.3$ days, $n=36)$.

\section{Serum steroid hormone concentrations during postpartum anoestrus and in the oestrous cycle}

Serum steroid hormones, testosterone, $5 \alpha$-DHT, progesterone, pregnenolone, $E_{1}$ and $E_{2}$ stayed at low levels during postpartum anoestrus (Table 2). The time from calving ( 15 to 44 days) did not affect the basal concentrations of steroids during the anoestrus period. During the luteal phase, testosterone concentrations remained at basal levels, but those of $5 \alpha$-DHT increased distinctly in the luteal phase (Table 2). As expected, progesterone concentrations were elevated in the luteal phase and also pregnenolone seemed to be increased at that phase of the oestrous cycle (Table 2). On the other

Table 1. Beginning of ovarian luteal activity (milk progesterone $>10 \mathrm{nmol} / \mathrm{l}$ ) at various periods after parturition in 2 breeds, Ayrshire (Ay) and Friesian (Fr) and 2 feeding groups, hay $(\mathrm{H})$ and silage $(\mathrm{S})$.

\begin{tabular}{|c|c|c|c|c|c|c|}
\hline \multirow[b]{2}{*}{$\begin{array}{l}\text { Days from } \\
\text { parturition }\end{array}$} & \multicolumn{2}{|c|}{ Breed } & \multicolumn{2}{|c|}{ Feeding } & \multirow[b]{2}{*}{$\begin{array}{l}\text { Total } \\
\mathrm{n}=47\end{array}$} & \multirow[b]{2}{*}{$\begin{array}{c}\text { Cumu- } \\
\text { lative }\end{array}$} \\
\hline & $\begin{array}{c}\text { Ay } \\
n=22\end{array}$ & $\begin{array}{c}\mathrm{Fr} \\
\mathrm{n}=25\end{array}$ & $\begin{array}{c}H \\
n=28\end{array}$ & $\begin{array}{c}S \\
n=19\end{array}$ & & \\
\hline 25 & $32 \%$ & $24 \%$ & $18 \%$ & $42 \%$ & $28 \%$ & $28 \%$ \\
\hline $26-40$ & $55 \%$ & $52 \%$ & $57 \%$ & $47 \%$ & $53 \%$ & $81 \%$ \\
\hline $41-$ & $13 \%$ & $24 \%$ & $25 \%$ & $11 \%$ & $19 \%$ & $100 \%$ \\
\hline$x \pm$ S.D. (days) & $\begin{array}{c}30.3 \\
\pm 8.6\end{array}$ & $\begin{array}{c}32.3 \\
\pm 11.0\end{array}$ & $\begin{array}{c}33.4 \\
\pm 10.3\end{array}$ & $\begin{array}{c}28.4 \\
\pm 8.7\end{array}$ & $\begin{array}{c}31.4 \\
\pm 9.9\end{array}$ & \\
\hline
\end{tabular}


Table 2. Bovine serum steroid concentrations (mean \pm S.D.) at postpartum anoestrus and during luteal and follicular phases.

\begin{tabular}{|c|c|c|c|}
\hline Steroid & $\begin{array}{l}\text { Postpartum } \\
\text { anoestrus }\end{array}$ & $\begin{array}{l}\text { Luteal } \\
\text { phase }\end{array}$ & $\begin{array}{l}\text { Follicular } \\
\text { phase }\end{array}$ \\
\hline $\begin{array}{l}\text { Testosterone } \\
(\mathrm{pmol} / \mathrm{l})\end{array}$ & $\begin{array}{l}13.2 \pm 9.4 \\
n=29\end{array}$ & $\begin{array}{l}16.3 \pm 11.1 \\
n=26\end{array}$ & $\begin{array}{l}19.4 \pm 13.9 \\
\mathrm{n}=30\end{array}$ \\
\hline $\begin{array}{l}5 \alpha-\mathrm{DHT} \\
(\mathrm{pmol} / \mathrm{l})\end{array}$ & $\begin{array}{l}59.5 \pm 19.6 \\
\mathrm{n}=29\end{array}$ & $\begin{array}{l}154.0 \pm 83.8 \\
n=26 \\
\text { IL }\end{array}$ & $\begin{array}{l}81.8 \pm 47.4 \\
n=30\end{array}$ \\
\hline $\begin{array}{l}\text { Progesterone } \\
(\mathrm{nmol} / \mathrm{l})\end{array}$ & $\begin{array}{l}0.34 \pm 0.42 \\
\mathrm{n}=29 \\
L_{* \star \star}\end{array}$ & $\begin{array}{l}5.53 \pm 1.84 \\
\mathrm{n}=26\end{array}$ & $\begin{array}{l}0.65 \pm 0.50 \\
\mathrm{n}=30\end{array}$ \\
\hline $\begin{array}{l}\text { Pregnenolone } \\
(\mathrm{nmol} / \mathrm{l})\end{array}$ & $\begin{array}{l}0.67 \pm 0.31 \\
\mathrm{n}=29 \\
\end{array}$ & $\begin{array}{l}0.88 \pm 0.29 \\
n=26 \\
\perp L\end{array}$ & $\begin{array}{l}0.67 \pm 0.27 \\
n=30\end{array}$ \\
\hline $\begin{array}{l}\text { Oestrone } \\
\text { (pmol/l) }\end{array}$ & $\begin{array}{l}40.4 \pm 14.1 \\
n=16\end{array}$ & $\begin{array}{l}38.9 \pm 14.1 \\
n=20\end{array}$ & $\begin{array}{l}39.3 \pm 14.1 \\
\mathrm{n}=18\end{array}$ \\
\hline $\begin{array}{l}\text { Oestradiol } \\
(\mathrm{pmol} / \mathrm{l})\end{array}$ & $\begin{array}{l}17.6 \pm 5.9 \\
n=29\end{array}$ & $\begin{array}{l}14.7 \pm 5.5 \\
n=25\end{array}$ & $\begin{array}{l}16.2 \pm 7.4 \\
n=30\end{array}$ \\
\hline
\end{tabular}

Significances: ${ }^{*} p<0.05,{ }^{* * *} p<0.001$

$\mathrm{n}=$ number of samples

hand, $E_{2}$ and $E_{1}$ concentrations were fairly low during the luteal phase. In the follicular phase, progesterone, $5 \alpha$-DHT and pregnenolone levels declined distinctly.

Two different feedings, silage and hay, did not appear to effect the secretion of steroid hormones during postpartum anoestrus, during the luteal phase or in the follicular phase. Likewise, no differences were observed between the 2 breeds, Ayrshire and Friesian.

We next studied hormonal changes during the oestrous cycle in greater detail. During the luteal phase, serum progesterone concentrations increased, being highest in middioestrus and thereafter declining (Fig. 1). Changes in pregnenolone and $5 \alpha$-DHT concentrations followed progesterone levels, but the highest concentrations were detected in late dioestrus (Figs. 1 and 2).
From late dioestrus to pro-oestrus the decline of serum progesterone concentrations was followed by decreasing $5 \alpha$-DHT and pregnenolone levels, but $E_{2}$ concentrations seemed to increase slightly in pro-oestrus (Figs. 1, 2 and 3). After pro-oestrus, serum $5 \alpha$-DHT concentrations rose again, while those of testosterone remained at basal levels throughout the oestrous cycle (Figs. 2). Progesterone levels correlated with those of pregnenolone $(\mathrm{p}<0.01)$ and $5 \alpha$-DHT $(\mathrm{p}<$ 0.001 ). Statistical evaluations of contemporaneous progesterone levels in the milk and in serum showed good correlation ( $p<$ 0.001).

To verify the elevation of serum $5 \alpha$-DHT and pregnenolone at the luteal phase of the bovine oestrous cycle, 46 extra blood samples were collected from Finnish dairy cows (Ayrshire and Friesian breeds) at a slaugh- 


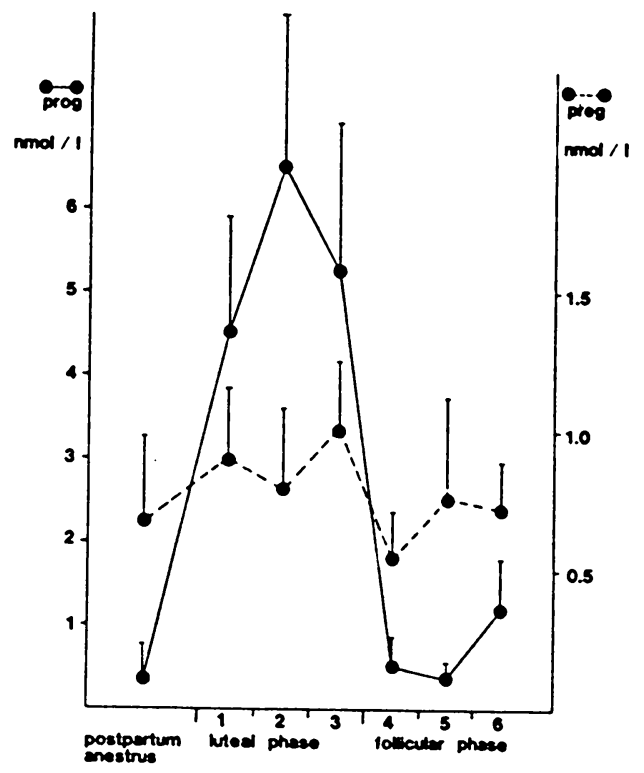

Figure 1. Changes of progesterone (prog) and pregnenolone (preg) concentration (mean \pm S.D.) in bovine serum at nostpartum anoestrus and during the oestrous cycle. Luteal and follicular phases are divided into the following periods: early (1), middle (2) and late (3) luteal phase, and pro-oestrus (4), oestrus (5) and metoestrus (6).

ter-house. The animals were examined by rectal palpation of the genitalia to exclude those which had abnormalities in reproductive function. The animals were sacrificed and blood samples collected from jugular veins without anticoagulant. The uterus and ovaries were examined macroscopically. In this study, bovine serum $5 \alpha$-DHT concentrations $(298 \pm 93 \mathrm{pmol} / \mathrm{l}, \mathrm{n}=22)$ during progesterone production (serum progesterone over $2.7 \mathrm{nmol} / \mathrm{l}$ ), were distinctly higher $(\mathrm{p}<0.001)$ than the concentrations $(201 \pm$ $67, n=24)$ in animals with low $(<2.7$ $\mathrm{nmol} / \mathrm{l})$ serum progesterone levels. Correspondingly, serum pregnenolone concentrations were $1.3 \pm 0.8 \mathrm{nmol} / \mathrm{l}(\mathrm{n}=22)$ during progesterone production and $1.0 \pm 0.4$

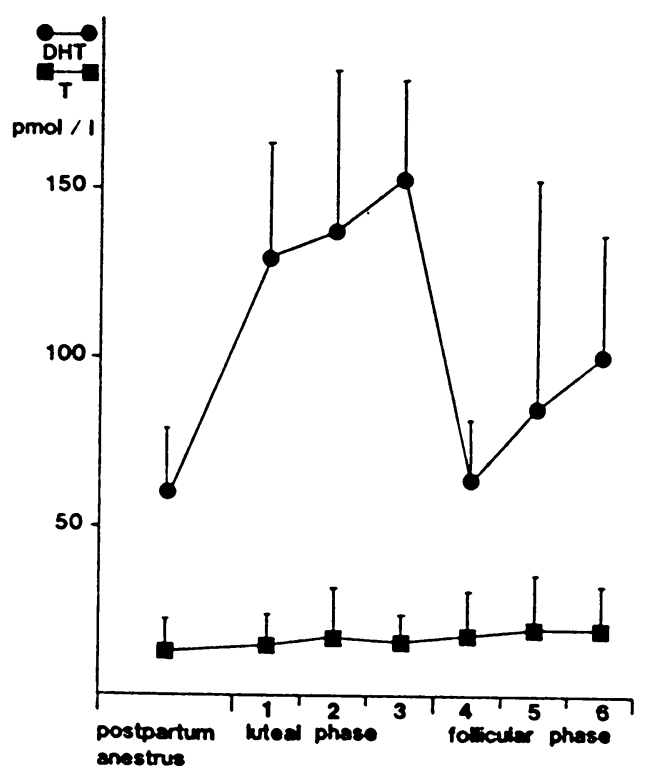

Figure 2. Changes in testosterone $(\mathrm{T})$ and $5 \alpha$ dihydrotestosterone (DHT) concentrations in bovine serum at postpartum anoestrus and during the oestrous cycle. For other details, see legend to Fig. 1.

$\mathrm{nmol} / \mathrm{l}(\mathrm{n}=24)$ in animals with low serum progesterone levels.

\section{Serum SHBG concentrations}

Bovine serum SHBG concentrations were very stable in various physiological conditions. At postpartum anoestrus, the SHBG concentration was $99.7 \pm 14.6(\mathrm{SD}) \mathrm{nmol} / \mathrm{l}$ $(n=29)$ and it remained constant from parturition to sampling (15-44 days). Concentrations of SHBG were also unchanged during the follicular phase of the cycle. Serum SHBG values in pro-oestrus, oestrus and metoestrus were $105.1 \pm 15.7(n=11)$, $109.5 \pm 11.8(\mathrm{n}=11)$ and $103.4 \pm 10.9$ $\mathrm{nmol} / \mathrm{l}(\mathrm{n}=8)$ respectively. During the luteal phase, SHBG concentrations remained at 


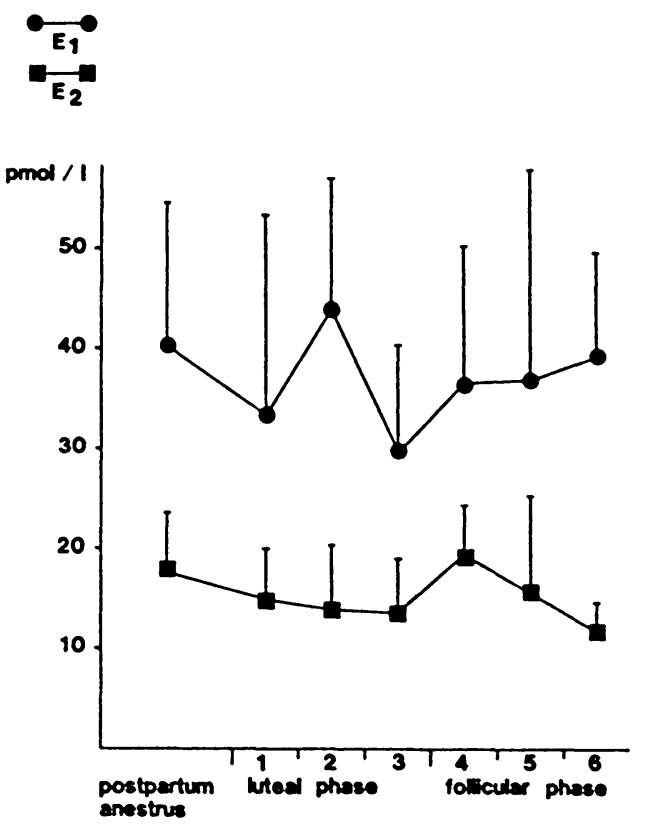

Figure 3. Changes in oestrone $\left(E_{1}\right)$ and oestradiol-17 $\beta\left(E_{2}\right)$ concentrations in bovine serum at postpartum anoestrus and during the oestrous cycle. For other details, see legend to Fig. 1.

the same levels (early, middle and late diestrus: $102.3 \pm 12.9(\mathrm{n}=9), 106.8 \pm 16.0$ $(\mathrm{n}=11)$ and $101.9 \pm 20.2 \mathrm{nmol} / \mathrm{l}(\mathrm{n}=6)$ respectively). There were no differences in serum SHBG levels between the 2 feeding groups or the 2 breeds, Ayrshire and Friesian. No correlations were observed between serum SHBG and 5 $\alpha$-DHT (or other steroid) concentrations. SHBG concentrations in the sera of pregnant cows (measured between days 52-274 of pregnancy, $n=15$ ) stayed at the same levels as those in non-pregnant animals. Competition assays showed that $5 \alpha$-DHT bound to SHBG with the highest affinity. Binding of testosterone was only 1 third of $5 \alpha$-DHT-binding and that of $E_{2}$ only about $5 \%$ (Table 3 ). The results of the competition experiments were similar in sera from 5 different animals.
Table 3. Relative binding affinities (RBAs) of various steroid hormones to bovine SHBG in vitro. Ranges of values are shown. Sera from 5 different animals were employed.

\begin{tabular}{ll}
\hline Steroid & RBA (\%) \\
\hline $5 \alpha$-DHT & 100 \\
Testosterone & $30-40$ \\
Estradiol-17 $\beta$ & $4-6$ \\
Progesterone & $0.5-1.3$ \\
\hline
\end{tabular}

\section{Discussion}

Using milk progesterone profils to monitor ovarian cyclic activity, we have shown that cows resumed ovarian cyclicity $31.4 \pm 9.9$ (S.D.) days after calving. The postpartum anoestrus period has shown itself to be slightly shorter in some other studies (Lamming \& Bulman 1976, Bulman \& Lamming 1978). In our material the start of ovarian cyclic activity varied between animals but in $81 \%$, ovarian progesterone production began by day 40 after calving. Some other investigators (van de Wiel et al. 1979, Bulman \& Lamming 1978) have reported that over $90 \%$ of dairy cows had resumed ovarian cyclicity within 40 days postpartum. The first luteal phase can be shorter and progesterone concentrations lower than that observed during a normal cycle (Schams et al. 1978, Stevenson \& Britt 1979, Webb et al. 1980). In our material $34 \%$ of the animals exhibited short luteal phases (milk progesterone $>10 \mathrm{nmol} / \mathrm{l}$ and duration of oestrous cycle $<17$ days) before normal oestrous cycles. Reasons for these irregular cycles have been postulated by many authors but a general consensus has not yet been reached. Cows fed with silage appeared to begin ovarian cyclic activity slightly earlier than those fed with hay after parturition. The difference between the 2 groups was, however, not significant. 
Changes of progesterone concentrations in bovine serum have previously been characterized in physiological and pathological conditions by many authors. Bovine serum progesterone profiles are therefore well established and can be used as the basis for evaluation of the stage of oestrus. High progesterone concentrations in bovine serum are produced by an active corpus luteum at dioestrus. In our study high progesterone concentrations were accompanied by elevated levels of pregnenolone, the precursor of progesterone. A similar elevation of pregnenolone concentrations in the luteal phase has previously been observed in human serum (Apter et al. 1976). Pregnenolone concentrations in womens' sera are at low but detactable levels (Apter et al. 1976). Hence, previous authors have concluded that pregnenolone is produced by both the follicular ovary (Apter et al. 1976) and the adrenal cortex (Bermudez et al. 1970, Jänne et al. 1967). These conclusions are supported by the fact that pregnenolone can be detected in the sera of ovariectomized ewes (McKay et al. 1987). However, distinctly higher serum concentrations of pregnenolone have been reported in the mid-luteal phase than at oestrus in ewes (McKay et al. 1987).

Concentrations of $5 \alpha$-DHT in bovine serum were significantly ( $p<0.001$ ) higher in the luteal phase than during postpartum anoestrus or in the follicular phase. This observation suggests that $5 \alpha$-DHT is produced by the corpus luteum. However, bovine serum testosterone concentrations remained at low levels in the luteal phase, in contrast to the situation in humans (Apter et al. 1976). Bovine serum $5 \alpha$-DHT concentrations in our study were several times higher than testosterone concentrations. One explanation for this could be rapid conversion of testosterone to $5 a$-DHT in cows. No cross-reactions were observed between progesterone,
$5 \alpha$-DHT or pregnenolone in our radioimmunoassays. Bovine serum $E_{1}$ and $E_{2}$ concentrations are low compared with the levels of these steroids in human serum. In our study, serum $E_{2}$ concentrations were similar to those reported previously, but the preovulatory elevations were smaller than in other investigations (Glencross et al. 1973, Dobson \& Dean 1974, Schallenberger et al. 1985). To detect the preovulatory peak of $\mathrm{E}_{2}$ elevation, consecutive measurements of this steroid should be carried out in the preovulatory phase of the oestrous cycle.

In Scatchard-type analysis, using $\left[{ }^{3} \mathrm{H}\right] 5 \alpha$ DHT, the dissociation constant (Kd) was $1 \times$ $10^{-9} \mathrm{~mol} / \mathrm{l}$ at $22^{\circ} \mathrm{C}(\mathrm{n}=2)$ for bovine SHBG. This indicates slightly lower affinity than for human SHBG $\left(0.23-0.28 \times 10^{-9} \mathrm{~mol} / \mathrm{l}, \mathrm{n}=\right.$ 5) assayed in parallel (results not shown). Suzuki et al. (1977) reported $\mathrm{Ka}=1.1 \times 10^{8}$ $\mathrm{mol} / \mathrm{l}$ (equivalent to $\mathrm{Kd}=9 \times 10^{-9} \mathrm{~mol} / \mathrm{l}$ ) for bovine serum at $4^{\circ} \mathrm{C}$.

The RBA values (Table 3) obtained for testosterone and $E_{2}$ were lower than those previously reported by Schrimanker et al. (1985) for bovine serum, but they were similar to those reported by Tabei et al. (1978) for dog SHBG (testosterone, $\mathrm{E}_{2}$ and progesterone c.f. $5 \alpha-D H T)$. In comparison to human SHBG (Dunn et al. 1981) the figures (c.f. $5 \alpha$-DHT) were similar for testosterone and progesterone, but lower for $\mathrm{E}_{2}$ (4-6\% vs. $22 \%$ ). To our knowledge, the circulating concentrations of bovine SHBG have not previously been reported. They were consistently high (almost $100 \mathrm{nmol} / \mathrm{l})$ in comparison to those of women (about $53 \mathrm{nmol} / \mathrm{l}$; Apter et al. 1984). No change in SHBG concentrations was observed over the oestrous cycle, and, in clear contrast to humans, the levels remained constant up to late pregnancy. Again, in comparison to humans, cows have relatively low circulating steroid concentrations (of those measured here) and 
high SHBG. Thus the biological effects of these sex steroids are manifest in the presence of a very high molar ratio of SHBG. This finding is very challenging. Despite very low circulating $E_{2}$ and high SHBG concentrations, the biological effects of $E_{2}$ were very clear in the animals, as evidenced by physical signs of oestrus and, for example, by induction of $E_{2}$ and progesterone receptor synthesis (Vesanen et al. 1988). One explanation may be that, assuming that only non-bound steroids are "available" for target tissues, the low binding affinity of $E_{2}$ to SHBG would allow relatively high available $E_{2}$ concentrations in bovine serum. A contrasting explanation is based on findings that SHBG appears to prolong the metabolic clearance rate of some sex steroids and it could also be important in transport of steroids to target organs (Siiteri et al. 1982). In some tissues, binding protein-steroid complexes may enter the cells (Rosner et al. 1986, Hsu et al. 1986). The present data do not allow final conclusions to explain the high biological efficacy of the low circulating $E_{2}$ concentrations in the presence of high SHBG concentrations in the cow.

\section{Acknowledgements}

This study was supported by grants from the Research Council for Medicine, and the Research Council for Agriculture and Forestry, of the Academy of Finland.

\section{References}

Apter D, Jänne O, Karvonen P, Vihko R: Simultaneous determination of five sex hormones in human serum by radioimmunoassay after chromatography on lipidex-5000. Clin. Chem. 1976, 22, 32-38.

Apter D, Bolton N, Hammond G, Vihko R: Serum sex hormone-binding globulin during puberty in girls and in different types of adolescent menstrual cycles. Acta endocr. (Kbh.) 1984, 107, 413-419.
Bermudez J, Doerr P. Lipsett M: Measurement of pregnenolone in blood. Steroids 1970, 16, 505 -512 .

Bolton N, Ruokonen A, Vihko R: Stimulation of the synthesis of steroids and steroid sulphates in human testicular tissue in vitro by hCG and by 8-bromo-cyclic AMP. J. Steroid Biochem. 1985, 22, 481-485.

Bulman D, Lamming GE: Milk progesterone levels in relation to conception, repeat breeding and factors influencing acyclicity in dairy cows. J. Reprod. Fertil. 1978, 54, 447-458.

Bulman D, McKibbin P, Appleyard $W$, Lamming $G E$ : Effect of a progesterone-releasing intravaginal device on the milk progesterone levels, vaginal flora, milk yield and fertility of cyclic and non-cyclic dairy cows. J. Reprod. Fert. 1978, 53, 289-296.

Dobson H, Dean P: Radioimmunoassay of oestrone, oestradiol- $17 \alpha$ and $-17 \beta$ in bovine plasma during the oestrous cycle and last stages of pregnancy. J. Endocr. 1974, 61, 479-486.

Dobson H: Plasma gonadotropins and oestradiol during oestrus in the cow. J. Reprod. Fertil. 1978, 52, 51-53.

Dunn J, Nisula B, Rodbard D: Transport of steroid hormones: Binding of 21 endogenous steroids to both testosterone-binding globulin and corticosteroid-binding globulin in human plasma. J. Clin. Endocr. 1981, 53, 58-68.

Glencross R, Munro I, Senior B, Pope G: Concentrations of oestradiol-17 $\beta$, oestrone and progesterone in jugular venous plasma of cows during the oestrous cycle and in early pregnancy. Acta endocr. (Kbh.) 1973, 73, 374 384.

Hammond $G$, Ahonen $V$, Vihko $R$ : The radioimmunoassay of testosterone, $5 \alpha$-dihydrotestosterone and their precursors in the human testis. J. Androl. (suppl.) 1978, 2, 391-399.

Hammond GL, Lähteenmäki PLA: A versatile method for the determination of serum cortisol binding globulin and sex hormone binding globulin binding capacities. Clin. Chim. Acta 1983, 132, 101-110.

Heap R, Holdsworth R, Gadsby J, Laing J, Walters $D$ : Pregnancy diagnosis in the cow from 
milk progesterone concentration. Brit. vet. J. 1976, 132, 445-463.

Hoffmann B, Günzler $O$, Hamburger $R$, Schmidt $W$ : Milk progesterone as a parameter for fertility control in cattle; methodological approaches and present status of application in Germany. Brit. vet. J. 1976, 132, 469-476.

Hsu B, Siiteri $P$, Kuhn R: Interactions between corticosteroid-binding globulin (CBG) and target tissue. In: Forest MG, Pugeat $M$ (eds.): Binding Proteins of Steroid Hormones. Colloque Inserm. John Libbey Eurotext Ltd., London 1986, 149, pp. 577-591.

Jänne $O$, Luukkainen $T$, Vihko $R$ : Solvolyzable steroid conjugates in human plasma after metyrapone administration. Eur. J. Steroids 1967, 2, 457-471.

Jänne $O$, Apter D, Vihko $R$ : Assay of testosterone, progesterone and 17a-hydroxyprogesterone in human plasma by radioimmunoassay after separation on hydroxyalkoxypropyl Sephadex. J. Steroid Biochem. 1974, 5, 155-162.

Lamming GE, Bulman D: The use of milk progesterone radioimmunoassay in the diagnosis and treatment of subfertility in dairy cows. Brit. vet. J. 1976, 132, 507-517.

Leinonen P: Estrone and estradiol concentrations in the testis and spermatic and peripheral venous blood of elderly men: the influence of estrogen treatment. J. Steroid Biochem. 1980, 13, 737-742.

McKay S, Jenkin G, Thorburn G: Peripheral plasma concentrations of pregnenolone sulphate, pregnenolone, progesterone and $20 \alpha$ hydroxy-4-pregnen-3-one in ewes throughout the oestrous cycle. J. Endocr. 1987, 113, 231-237.

Rosner $W$, Khan $M$, Romas $N$, Hryb D: Interactions of plasma steroid-binding proteins with cell membranes. In: Forest MG, Pugeat M (eds.): Binding Proteins of Steroid Hormones. Colloque Inserm, John Libbey Eurotext Ltd., London 1986, 149, pp. 567-575.

Schallenberger E, Schöndorfer A, Walter D: Gonadotrophins and ovarian steroids in cattle. I. Pulsatile changes of concentrations in the ju- gular vein throughout the oestrous cycle. Acta endocr. (Kbh.) 1985, 108, 312-321.

Schams D, Schallenberger E, Menzer $K$, Stangl J, Zottmeier $K$, Hoffman B, Karg $H$ : Profiles of $\mathrm{LH}$, FSH and progesterone in postpartum dairy cows and their relationship to the commencement of cyclic functions. Theriogenology 1978, 10, 453-468.

Shemesh $M$, Ayalon $N$, Shalev $E$, Nerya $A$, Schindler $H$, Milguir $F$ : Milk progesterone measurement in dairy cows: correlation with estrus and pregnancy determination. Theriogenology 1978, 9, 343-352.

Shrimanker K, Salter L, Patterson R: Binding of steroid hormones and anabolic agents to bovine sex-hormone binding globulin. Horm. Metab. Res. 1985, 17, 454-457.

Siiteri P, Murai J, Hammond G: The serum transport of steroid hormones. Recent Progr. Hormone Res. 1982, 38, 452-510.

Stevenson J, Britt J: Relationship among luteinizing hormone, estradiol, progesterone, glucocorticoids, milk yield, body weight and postpartum ovarian activity in Holstein cows. J. Anim. Sci. 1979, 47, 570-577.

Suzuki Y, Hagaki E, Mori H, Hosoya T: Isolation of testosterone-binding globulin from bovine serum by affinity chromatography and its molecular characterization. J. Biochem. 1977, 81. 1721-1731.

Suzuki $Y$, Sinohara $H$ : Subunit structure of sexsteroid-binding plasma proteins from man, cattle, dog and rabbit. J. Biochem. 1984, 96, 751-759.

Tabei T, Mickelson K, Neuhaus S, Petra P: Sex steroid binding protein (SBP) in dog plasma. J. Steroid Biochem. 1978, 9, 983-988.

Wallenstein S, Zucker C, Fleiss J: Some statistical methods useful in circulation research. Circulat. Res. 1980, 47, 1-9.

Van de Wiel D, Kalis C, Nasir Hussain Shah S: Combined use of milk progesterone profiles, clinical examination and oestrus observation for the study of fertility in the postpartum period of dairy cows. Brit. vet. J. 1979, 135, 568-577. 
Webb $R$, Lamming GE, Haynes $N$, Foxcroft $G$ : Plasma progesterone and gonadotropin concentrations and ovarian activity in postpartum dairy cows. J. Reprod. Fertil. 1980, 59, 133-143.

Vesanen M, Isomaa $V$, Alanko M, Vihko R: Cytosol estrogen and progesterone receptors in bovine endometrium after uterine involution postpartum and in the estrous cycle. Anim. Reprod. Sci. 1988, 17, 9-20.

\section{Sammanfattning}

Koncentrationerna av steroidhormoner och SHBG hos kor postpartum och under sexualcykeln.

Två koraser (Ayrshire och Friesian) med olika utfodringar studerades under en postpartum period. Progesteronkoncentrationerna $\mathrm{i}$ mjölk ökade en månad efter kalvningen men varken ras eller utfodring påverkade igångsättningen av sexualcykler. Koncentrationerna av steroidhormoner (testosteron, dihydrotestosteron, progesteron, pregnenolon, estradiol och estron) i blodet förblev på en oförändrad låg nivå under den postpartala anestrusperioden. Därefter konstaterades en ökning av progesteron i blodet samtidigt med en signifikant ökning av dihydrotestosteron och pregnenolon. Koncentrationerna minskade igen under den follikulära fasen. Koncentrationerna av serum SHBG (sex hormone-binding globulin) var relativt höga men någon variation på grund af sexualcykler förekom inte. Koncentrationen av SHBG i blodet ökade inte under dräktigheten, vilket är fallet hos gravida kvinnor.

(Received September 4, 1989; accepted November 23, 1989).

Reprints may be requested from: M. Vesanen, Department of Clinical Chemistry, University of Oulu, SF-90220 Oulu, Finland. 